\title{
Second hand smoke and risk assessment: what was in it for the tobacco industry?
}

\author{
Norbert Hirschhorn, Stella Aguinaga Bialous
}

\begin{abstract}
Objective-To describe how the tobacco industry attempted to trivialise the health risks of second hand smoke (SHS) by both questioning the science of risk assessment of low dose exposure to other environmental toxins, and by comparing SHS to such substances about which debate might still exist.
\end{abstract}

Methods-Analysis of tobacco industry documents made public as part of the settlement of litigation in the USA (Minnesota trial and the Master Settlement Agreement) and available on the internet. Search terms included: risk assessment, low dose exposure, and the names of key players and organisations.

Results/conclusion-The tobacco industry developed a well coordinated, multipronged strategy to create doubt about research on exposure to SHS by trying to link it to the broader discussion of risk assessment of low doses of a number of toxins whose disease burden may still be a matter of scientific debate, thus trying to make SHS their equivalent; and by attempting, through third party organisations and persons, to impugn the agencies using risk assessment to establish SHS as a hazard.

(Tobacco Control 2001;10:375-382)

Keywords: tobacco industry; risk assessment; environmental tobacco smoke; ETS; second hand smoke; SHS

Over the past two decades evidence has accumulated to indict passive smoking as an important health hazard. Exposure to second hand smoke causes respiratory diseases in children and sudden infant death syndrome, lung cancer, heart disease, breast cancer and stroke in non-smoking adults, ${ }^{1-5}$ among other illnesses. It has been estimated that passive smoke is responsible for over 50000 deaths in the USA each year. ${ }^{6}$

Key scientific and regulatory agencies throughout the world have declared environmental tobacco smoke (ETS) a risk to public health..$^{711}$ The tobacco industry has understood for over two decades that the matter of protection of non-smokers' rights is, in the words of the well-known 1978 Roper Organization study, "the most dangerous development to the viability of the tobacco industry that has yet occurred". ${ }^{12}$ The acceptance of environmental tobacco smoke as a toxic contaminant, not merely an irritant, gives momentum and supports legislation to ban public smoking to protect the health of non-smokers. Bans on smoking in workplaces and public areas lead to an overall decrease in consumption $^{13-16}$ and are powerful incentives for smokers to quit, as a Philip Morris (PM) official noted in 1994:

Smoking bans are the biggest challenge we have ever faced. Quit rate goes from $5 \%$ to $21 \%$ when smokers work in non-smoking environments. ${ }^{17}$

Drops in consumption in turn leads to a loss of profits for the tobacco industry. ${ }^{14}$ As one PM document states:

Financial impact of smoking bans will be tremendous. Three to five fewer cigarettes per day will reduce annual manufacturer profits a billion dollar plus per year. ${ }^{18}$

Thus tobacco industry has fought to protect sales and profits by creating doubt about second hand smoke as a cause of disease, from the earliest published studies in the $1980 \mathrm{~s}^{1920}$ up to the present, despite the industry's own studies. ${ }^{21}$ To this end, the industry has used a variety of strategies: secretly recruited witnesses and consultants; stage managed conferences; articles by paid surrogates placed in the media; subsidised research; and creation or sponsorship of third party groups that publicly support the industry position. ${ }^{22-27}$

The National Research Council defines risk assessment as

... the evaluation on information on the hazardous properties of substances, on the extent of human exposure to them, and on the characterization of the resulting risk. Risk assessment is not a single, fixed method of analysis. Rather, it is a systematic approach to organizing and analyzing scientific knowledge and information for potentially hazardous activities or for substances that might pose risks under specified conditions. . . .risk assessment can be divided into four steps: hazard identification, dose-response assessment, exposure assessment, and risk characterization. ${ }^{28}$ (page 4)

When the US Environmental Protection Agency (EPA) issued a report in 1992 declaring environmental tobacco smoke a group A (human) carcinogen, ${ }^{7}$ it became a matter of urgency for the tobacco industry to discredit the EPA entirely, and its methods of risk assessment generally, not just on SHS. The 
industry was concerned that widespread acceptance of the EPA report by policy makers and other regulatory agencies would lead to a worldwide movement to restrict smoking in workplaces and public places. ${ }^{29-32}$

This paper builds on the research of others, mainly Ong and Glantz, ${ }^{23} 33$ who described the sophisticated, worldwide, scientific, political, and media strategies used by the tobacco industry to deny the health risks of second hand smoke, to address the complex web of third party organisations the tobacco industry utilised when implementing one important ingredient of all its "anti-SHS" strategies: to question the validity of the ongoing scientific and political discussion surrounding risk assessment and its application to second hand smoke exposure. It shows the tobacco industry involvement with risk assessment in its intention to trivialise the health hazards of SHS. The evidence is presented in two categories: linkage of SHS to other low dose exposures, and use of third party organisations to discredit the regulatory agencies, and their methodology, that sought to classify SHS as an environmental health hazard.

\section{Methods}

From January to June 2000, we conducted a systematic search and analysis of the tobacco industry documents available on the internet and made public as a result of the settlement of the state of Minnesota and Blue Cross/Blue Shield of Minnesota versus Philip Morris Inc, et $a l$, and other litigation and the Master Settlement Agreement between the US tobacco companies and the US states attorney generals. We focused principally on document titles, letters, telexes, and memos using the following key words: risk assessment, environmental exposure, risk analysis and environmental tobacco smoke in a variety of combinations. We also searched the names of key players and organisations identified through the documents. The majority of documents come from the Philip Morris company website (www.pmdocs.com), which was expected since Philip Morris took the lead in this initiative. ${ }^{31} 32$

Research using tobacco industry documents available on the internet is limited in scope since only documents that were produced as part of the discovery process in a given legal case are available, and answers to the research questions could potentially be incompletethat is, it is possible that other documents exist which would be relevant to this research, but they are not, as yet, available to the public. Also, there is a large cache of documents from the British American Tobacco Company at a document depository in Guildford, England. The majority of these documents are not available on the internet. An in-person search of the Guildford depository was not feasible for this research and it is possible that documents of relevance would have been found there.

\section{Findings}

THE STRATEGY TO LINK SHS TO OTHER LOW DOSE EXPOSURES

For the past quarter century, upon pressure from environmental, labour and consumer groups, US federal and state regulatory agencies have been applying increasingly stringent standards for product, occupational, and environmental safety. Large industries have made efforts to slow or reverse such regulations. ${ }^{34}$

RJ Reynolds (RJR) associate director of scientific affairs Frank Colby argued the necessity for the tobacco industry to coordinate with other industries to counteract the trend. Colby wrote to RJR Counsel SB Witt stating:

More than a year ago I sent a memorandum to Mr. Crohn [RJR attorney Max $\mathrm{Crohn}^{35}$ ] . . on

'COMMON INTERESTS OF U.S. INDUSTRIES, INCLUDING THE TOBACCO INDUSTRY, ON ENVIRONMENTAL HEALTH CONTROVERSIES....' I like to suggest again that top executives of the Tobacco Industry...should get together on a one-to-one basis with one or more of their peers in the chemical industry and/or the petroleum industry, and/or the plastics industry, etc ... The purpose would be to point out that it is scientifically invalid and politically shortsighted for one industry to try to put blame for allegedly environmentally caused health effects on other industries. After more than one year I have yet to see a sign [of] ... 'reaching out' process is currently under way. ${ }^{36}$

By the mid 1980s RJR and other tobacco companies saw that such alliances were increasingly necessary with both US states and Congress were passing consumer product liability laws, and with the 1986 publication of the US Surgeon General report on the health consequences of involuntary smoking. ${ }^{8}$

In 1994 a RJ Reynolds document titled, "Second hand smoke plan," recognised the potential consequences for the tobacco industry of the growing concern about the hazards of SHS and proposed actions beyond dealing with SHS:

Federal agencies, Congress and state and local governments are pursuing increasingly aggressive regulatory measures to limit exposure to second hand smoke, citing an alleged risk or hazard to the non-smoking public. We believe this increasingly threatening regulatory environment warrants a more aggressive and intense public affairs outreach program to bring fairness and accountability to the policy making process.

The stakes for RJRT and the industry have never been higher. We need to act immediately, within the next $60-90$ days ... We should be prepared to take greater risks than ever before. And we need to join the battle or engage the enemy on as many fronts as possible. ${ }^{37}$

The document proceeds with suggestions on how the company can "join the battle". For example:

Increase the call for responsible use of science in formulating policy through a forum to debate and draw attention to the issue. Open to the media, the event participants could include scientists, risk assessment experts, legislators critical of improper use of science, syndicated columnists, science writers and policy reporters, 
and current and former health officials.

The forum could be held in Washington, DC and sponsored by a reputable think tank. Program should be broad enough to include a myriad of issues and concerns regarding various substances and issues, but would include SHS [second-hand smoke] as a centerpiece and current example. Could also include:

An overview of examples of where issues were driven by flawed science or without scientific support, such as SHS, pesticides, asbestos, ozone depletion, acid rain and resource depletion. A discussion of how sensationalism and unjustified media frenzies have effected behavioral or policy changes without scientific support, such as scares over alar, electromagnetic fields, polystyrene and other issues ... A segment on risk assessment that includes hypothetical risks vs. real risks and illustrates the level of risks associated with common and uncommon activities. This would put SHS in perspective. ${ }^{37}$

It is not clear whether or not this specific forum was ever organised, but as described below, several similar activities did take place, as part of the industry's strategy to question risk assessment methodology in general and its application to second hand smoke.

At a 1994 PM meeting, an unidentified participant noted down some of the specific ways the company was going to deal with the ETS issue, including how to discredit EPA's approach to risk assessment:

Build a coalition to address state level — address junk science-chlorinated water, EMF [electromagnetic forces], asbestos, etc. Educate media, public officials, general public about the impact of junk science, tax dollars ... Working with RJR [RJ Reynolds Tobacco Company] for a joint strategy in order to leverage resources and not step on each other toes. ${ }^{17}$

PM director of Corporate Affairs Matthew Winokur made it clear that when it came to second hand smoke, it was a matter of bundling it with all other risk assessments:

In the years following the publication of the risk assessment there has been a groundswell of concern in both the scientific community and in the media about what happens when science is either poorly designed or conducted and/or is used inappropriately by risk assessors and policy makers.

The most recent spate of coverage has been on breast implants. But there's more on dioxin, bendectin, agent orange breast cancers related to both abortion and alcohol consumption, diesel exhaust, etc. The point is with the question mark now raised about the validity and applicability of the science on all these issues, couldn't we package the ETS science as an example of the problems inherent with most of low risk epidemiology on which policy is being (poorly) based. That way we're not asking our target groups to take a stand on ETS alone. Yet they can single out ETS when they need to-and CRS [Congressional Research Service] as the latest/best criticism —as a case in point. ${ }^{38}$

Thus, it is clear that the strategy of addressing SHS within the context of criticising risk assessment methodology and other low dose exposure was in the agenda of the tobacco industry, not just of one company, and warranted the attention of high level executives and scientists.
THE STRATEGY TO USE THIRD PARTY ORGANISATIONS TO DISCREDIT THE REGULATORY AGENCIES SEEKING TO CLASSIFY SHS AS AN ENVIRONMENTAL HEALTH HAZARD AND THEIR METHODOLOGY With the publication of the 1992 EPA report, ${ }^{7}$ the tobacco industry intensified its efforts to create controversy over the hazards of SHS and to discredit EPA as an agency. A document outlining in more detail the ETS media strategy states:

"The credibility of EPA is defeatable, but not on the basis of ETS alone. It must be part of a larger mosaic that concentrates all of EPA's enemies against it at one time." ${ }^{32}$

In February 1993 Thomas Humber of PM's public relations firm Burson-Marsteller wrote PM vice-president for corporate affairs, Ellen Merlo that an "escalation of all ETS [regulatory and legislative] activities" called for a "coordinated, focused team effort, both within PM and within the industry." 31 Humber's plan outline describes, among other objectives, to "discredit the EPA report on ETS specifically and the EPA generally ...."31 and recommends, as part of a media strategy:

Thus, the only stories we should be seeking are those that:

- Demonstrate the scientific weaknesses of the EPA conclusions in consequential terms

- Put the risk in perspective

- Point to EPA excesses and mistakes unrelated to tobacco

- Demonstrate EPA “corruption"

- Re-evaluate the risk assessment process

- Stimulate non-tobacco industries, antiregulation groups and others to provide their own perspective in order to portray the EPA as an agency currently under siege..${ }^{31}$ [emphasis in original]

Humber's memo also describes the utilisation of some third party organisations, and suggests that the "next steps" include:

Explore a broader base of potential scientific allies, some of whom would speak to the issue of ETS, others who would address science, scientific methodologies, the science at EPA, and risks assessments in a broader sense. This is where we start to put the science of ETS into perspective. ${ }^{31}$

(Humber went on the become the president and CEO of the National Smokers' Alliance (NSA), created by PM. NSA was active in opposing smoking restrictions and bans throughout the USA. ${ }^{39}$ )

Among the "allies" were non-profit and forprofit organisations addressing the science of risk assessment and "sound science" (one of the industry's preferred terms in its attack of $\left.\mathrm{EPA}^{23}\right)$; sponsorship of non-profit and for-profit organisations addressing the science of risk assessment; and political coalitions of industrial groups (some created, others subsidised).

For example, Philip Morris provided funds to a for-profit agency called Multinational Business Services, Inc (MBS), headed by Jim Tozzi. In $1994 \mathrm{MBS}$ had a $\$ 300000$ contract with PM to, among other things:

(a) provide advice and counsel on developing and maintaining constructive relationships with governmental agencies involved in environmental 
issues, (b) research environmental matters and issues affecting PM USA to ensure that good credible science is duly considered in regulatory matters ...., (e) monitor congressional, federal and legislative publications and activities for items of interest related to environmental regulatory matters. ${ }^{40}$

(The contract was later increased to $\$ 610000 .^{40}$ )

Another document states that MBS was:

Working with us [PM] to develop materials designed to intensify the debate on the need forscientific standards on meta-analysis and epidemiology such as EMF, chlorinated water, and radon in water. ${ }^{41}$

Although the contract and other documents refer to environmental issues and not specifically to second hand smoke, Jim Tozzi and MBS were considerably involved on PM's attempt to discredit the International Agency for Research on Cancer's multicentre study on passive smoking specifically, ${ }^{33}$ and to question basic epidemiological methods for determining health risks generally. ${ }^{23}$

At the same address as MBS was Tozzi's Federal Focus, Inc, a non-profit company that also received funds from PM. ${ }^{42}$ A subunit of Federal Focus was the Institute for Regulatory Policy (IRP) ${ }^{43}$, which was also considered as a third party ally by PM, and which created additional layers of third party groups, further removed from PM itself. Burson-Marsteller's Tom Humber perceived IRP as especially successful in coordinating scientific and business groups around the issue of risk assessment and sound science. As Humber wrote:

IRP is an existing mechanism that currently is in the best position to assemble and mobilise a wide variety of business groups, corporations, local governments and other parties concerned about or victimized by EPA excesses.

Burson-Marsteller has worked with IRP . . . and has several clients who are among IRP's key supporters. $^{31}$

Another document explained that IRP successfully:

. . put together three different coalitions which support sound science-Coalition For Executive Order, Coalition for Moratorium on Risk Assessments, Coalition of Cities and States on Environmental Mandates. It is our view that the local government coalition is the most important. If they can become aggressive in support of requiring sound science, business support will naturally follow. ${ }^{41}$

IRP was headed by Thorne Auchter, former director of the US Occupational Health and Safety Administration (OSHA). ${ }^{44}$ In 1992 President George Bush appointed Auchter as a member of the Risk Assessment and Management Commission, ${ }^{45}$ that was established under the Clean Air Act Amendments of 1990 to "study the risk assessment process and how the process should be used in environmental decision-making". 46 Auchter served on the Commission until 1994. ${ }^{46}$ (In 1993, PM was paying $\$ 25000$ a month to IRP. ${ }^{41}$ )

Auchter actively tried to redefine the science of risk assessment. He authored a 10 page statement submitted to a 1994 OSHA public meeting on "The need for good epidemiology practices (GEPs) in studies used by the regulatory agencies." ${ }^{47}$ The statement contributed to PM's attempt to rewrite GEP, part of its strategy to discredit the epidemiological studies on second hand smoke, as described by Ong and Glantz. ${ }^{23}$ Auchter's statement was provided on Institute for Regulatory Policy letterhead but nowhere did Auchter reveal his source of income.

Auchter also involved himself, writing alternatively on IRP and MBS letterheads, in the discussions of the International Classification of Diseases, 9th revision, Clinical Modification (ICD-9-CM) at the National Center for Health Statistics (NCHS); he kept PM's Mayada Logue, who reported directly to PM vice president Steve Parrish, informed about the possibility, and consequences, of ICD-9 including second hand smoke as a disease. ${ }^{48}$ (The committee preparing ICD-9 was also considering the inclusion of other environmental substances such as asbestos, latex, silicone, dioxin, and PCBs. ${ }^{49}$ ICD-9 is an internationally accepted coding system used to standardised disease classification which is used in epidemiological research, health statistics, and medical billing.) Auchter suggested that during the public comments period,

"a third party write to the ICD and cite the problems associated with incorporating second-hand smoke as a classification in the ICD" [such as]:

(1) Multinational Business Services; (2) A physician; (3) A scientist such as a toxicologist; and (4) A state business trade association. ${ }^{48}$

Indeed, in an update provided by Auchter to Logue, $^{50}$ he states that three of the four suggested "third-party candidates" wrote letters of objection to the ICD-9 Coordination and Maintenance Committee: MBS, a toxicology consultant; and the Associated Industries of Florida Service Corporation, a business trade association from Florida concerned about the impact of SHS inclusion on workman's compensation. Auchter also stated that MBS continued "appropriate discussions with key people" in order to avoid the inclusion of second hand smoke in the ICD-9..$^{50-52}$

In this instance, however, Auchter was not successful. ICD-9 does include codes for exposure to asbestos, latex, and silicone. Second hand tobacco smoke (E869.4) is included under the heading of "Accidental poisoning by other gases and vapors" which also includes tear gas, freon, nitrogen oxides, sulfur dioxide, chlorine, and hydrocyanic gas. ${ }^{53}$

Philip Morris funded Jim Tozzi's Federal Focus; the latter, in turn, was one of the funders of the George C Marshall Institute in Washington DC. ${ }^{54}$ In 1994 the institute published a report called "Global warming and ozone hole controversies. A challenge to scientific judgment," written by its board chairman, Dr Frederick Seitz. While introducing the subject Seitz also listed a dozen other environmental substances whose dangers he considered controversial, including nuclear wastes, asbestos, acid emissions from burning coal, toxic waste disposal, genetic engineering, pesticides, and passive smoke. Referring to the 
latter he wrote, "there is no good scientific evidence that passive inhalation is truly dangerous under normal circumstances. ${ }^{~} 55$ It is clear that MBS's Jim Tozzi had access to early copies of this publication and was planning on using it to further PM's agenda through a symposium to discuss the report findings. ${ }^{54}$ This symposium was to be attended by "Federal employees as well as private sector interests". Tozzi recommended:

... that PM and other major associations affected by the topic areas [in the report] participate in the seminar and its funding. This would include the pesticide industry, automobile industry and chemical industry. ${ }^{54}$

In March 1994, Matthew Winokur, alerting his staff to the report, noted that:

What makes this report particularly significant is that it is authored by Dr Frederick Seitz, one of the most distinguished scientists in the US. Dr Seitz is past president of the National Academy of Sciences [he was President from 1962-1969] and President Emeritus of Rockefeller University. He is one of the most highly recognized scientists to challenge the prevailing view on ETS. ${ }^{56}$

What Winokur did not say was that in 1979 Seitz became a "permanent consultant" to cigarette maker RJ Reynolds. ${ }^{57}$ Seitz's report had potential for an international reach as PM Europe's Helene Lyberoupoulos suggested to her counterparts that:

You may wish to distribute the paper to your NMA's [National Manufacturers Associations, representing tobacco companies in each country] and Smokers Rights Groups to provide them with a tool for their communications/lobbying efforts. ${ }^{58}$

In addition, in $1992 \mathrm{PM}$ was considering staging a "Seitz Symposium", specifically targeting regulators, on matters seemingly remote from SHS but as part of its attack on the EPA:

Late 1 st quarter/early 2 nd quarter

Procedural Options for Addressing the Scientific Issue Highlighted in Global Warming and Ozone Hole Controversies, Dr Frederick Seitz of the George C Marshall Institute.

40-60 regulators-Ensure credible science

TASSC [The Advancement of Sound Science Coalition $]^{59}$

Jim Tozzi also tried to influence regulatory agencies that were considering listing dioxin as a "known human carcinogen". Why dioxin? IARC had taken that step with respect to the polychlorinated dibenzo-para-dioxin 2,3,7,8TCDD $^{60}$ based on the overall weight of evidence, which included animal experiments and epidemiological data, the way EPA was led to classify passive smoke as a group A (human) carcinogen. When in 1998 the US National Toxicology Program (NTP) sought to follow IARC's lead, Tozzi presented testimony on behalf of an organisation called the Center for Regulatory Effectiveness (CRE), stating that:

[CRE] is comprised of number of leading trade associations and companies that have an interest in the integrity of Federal Government processes that affect their interests and those of their customers and members. ${ }^{61}$
Tozzi and Auchter had established CRE in $1996,{ }^{62}$ a fact he did not reveal to NTP. Contrary to his testimony, CRE's current web page, which shows the same address as MBS and Federal Focus, lists but a four person advisory board (including Tozzi), and states that "CRE has no members." ${ }^{63}$ In his testimony, Tozzi provided no scientific analysis but attacked "the integrity of the NTP and subcommittee review process" ${ }^{61}$ and put his objection into a larger context of value to the tobacco industry:

More specifically, although [my comments] are directed at dioxin, they are also aimed at the terrible government-wide precedent that could result. ${ }^{61}$

In 1999 PM submitted comments concerning NTP's proposal to list passive smoke as a known human carcinogen. In its criticism, PM complained that NTP treated environmental tobacco smoke differently than diesel exhaust, accusing NTP of bias against tobacco: diesel was classified as "reasonably anticipated to be a human carcinogen" while ETS was to be classified as "known to be a human carcinogen," 64 in line with the epidemiological data. MBS's Jim Tozzi had discussions with NTP officials on this issues and one of the "primary outcomes of that conversation was NTP's willingness to consider a government-industry workshop on ETS. ${ }^{65}$ The NTP listed ETS as a human carcinogen in 2000."

Another coalition, created entirely by PM in 1993, was The Advancement of Sound Science Coalition (TASSC), a group of scientists, in an attempt to denigrate the way government, especially the EPA, used risk assessment. TASSC's role in the industry's ongoing effort to create controversy over the health hazards of ETS has been described in detail by Ong and Glantz. $^{23}$

The interdigitation of the various third party groups supported by PM may also be seen in the activities of an industry coalition called Coalition for Uniform Risk Evaluation (CURE). CURE was involved in the review of a 1993 proposal of a US Executive Order on regulatory reform that addressed, among other things, risk assessment. ${ }^{66}$ The membership list of CURE includes members of the electronic, forest and paper, plastics, and beverage industries; while cigarette companies were not direct members of the coalition, ${ }^{67}$ CURE was financially supported by PM to question a range of federal regulatory efforts:

Develop Local/State Official Risk Assessment Directed Toward the WRO/USA [Washington Relations Operations] CA Goals

Objective: To ensure synergy between the TASSC program, CURE, Federal Focus (Mayor/ Local Officials and Unfunded Mandates) and any other organizations that are persuing [sic] this avenue of questioning the risk factors of federal agencies.

Continued support through CURE $\$ 100,000 .{ }^{\prime 68}$

The proposed 1993 Executive Order was to include "principles of sound science, cost-benefit analysis and the use of 
risk-assessment for regulatory prioritization"; this was considered to represent "a tremendous victory for CURE" as stated in a memo to CURE members co-authored by Wayne Valis, a professional coalition manager for various industries concerned about federal regulation, and IRP's Thorne Auchter. ${ }^{66}$ This memo was forwarded by Auchter to Ted Lattanzio of PM, and by Lattanzio to several other senior executives, including Steve Parrish, PM senior vice president. ${ }^{66}$ On the memo, a hand written note from Auchter to Lattanzio states:

Ted-Note Item 7 on page 4 [of the attached report of a White House meeting on the proposed Executive Order] - the inconsistency language should be an area that will strengthen our efforts to re-open the ETS RA [Risk Assessment] - Thorne. ${ }^{66}$

The item Auchter refers to is part of the notes made by Lewis Freeman, of The Society of the Plastics Industry, Inc, who was representing CURE at the White House meeting. The item states that:

Within 90 days of the Executive Order, each agency shall submit for review those regulations that should be modified or eliminated because they are unrelated or are inconsistent with other regulatory requirements. ${ }^{66}$

Another lobby group funded by PM was the Citizens for a Sensible Environment, also called Citizens for a Sound Economy (CSE), which, said Burson-Marsteller's Tom Humber, was "well known to PM . . . and [in respect to ETS] is well-positioned to undertake a number of coalition-building activities." ${ }^{31}$ CSE was supported by PM in 1994 with a gift of $\$ 300000$. $^{34}$ (Other industries with polluting products have recently hired CSE as a policy think tank and political lobby, one that promises anonymity to its donors. ${ }^{69}$ )

\section{Conclusion}

For over two decades, the tobacco industry has mounted a sustained, coordinated, worldwide disinformation campaign, the aim of which is to denigrate the increasingly substantial evidence that SHS is an environmental health hazard. This campaign has scientific, public relations, and political arms, all in support of the industry's efforts to avoid or delay the passage of legislation and regulations restricting or banning smoking in public places.

Based on internal company documents, this paper has analysed one piece of this campaign: the effort to equate SHS with other toxic substances, which in low dose exposure may not cause disease. We show that, in the attempt to create this linkage, the tobacco industry, led by Philip Morris, has mounted an attack on the techniques of risk assessment as used by regulatory agencies, mainly the US EPA, to define a number of environmental health hazards. The industry has also attacked the utilisation of such risk assessment techniques in policymaking. Additionally, the reputation and credibility of such agencies as the US EPA and WHO/IARC has been seriously impugned.

The disinformation campaign replicates the classic mantra and methods of the tobacco

\section{What this paper adds}

For the past two decades the tobacco industry has mounted a coordinated, worldwide effort to dismiss the health hazards of second hand smoke (SHS). This disinformation campaign has scientific, political, and public relations components, many of which have been discussed in the published literature. This study analyses one key element of the tobacco industry's disinformation campaign on the issue of SHS: How the industry sought to trivialise the risks to health by linking exposure to SHS to exposure of other low dose substances about whose effects there is still debate. The principal methods used were to bring into doubt the techniques of risk assessment generally, and to get third party organisations and spokespersons to discredit those agencies specifically that used such measurements to detect the hazards of SHS.

industry that, for the past half century, continually denied the overwhelmingly proven harm caused by tobacco products. These methods included creation or subsidy of third party think tanks, citizen and corporate coalitions, and lobby groups; attempts to revise the science of environmental epidemiology, and use of industry sponsored research to influence legislators and the public.

Two questions may be fairly raised about our findings: (1) was the tobacco industry's effort not simply standard operating procedure for any corporation trying to protect its profits and its shareholders; and (2) was the effort successful? The answers to these questions are, in fact, related.

It is true that the unprecedented release of tobacco industry internal documents gives us a unique, even privileged, view of this particular industry's behaviour. It is also true that the tobacco industry has largely escaped the type of government regulatory and judicial oversight that, over the past decades, have brought clean air and water laws, safer food, fewer pesticides, better disposal of heavy metals and organic toxins, and greater occupational safety, among other public health benefits. To this extent, the tobacco industry seems to have succeeded in its efforts, thus far. Moreover, the bottom line in the industry's effort against bans on public exposure to tobacco smoke has always been to protect its profits. As of July 2001, Philip Morris has continued to post profits, being one of the best performing stocks on the Dow Jones Index. ${ }^{70}{ }^{71}$

What lessons can we learn from this paper and similar efforts to expose tobacco companies practices and behaviour? The health risks of many substances to which we are routinely exposed in low doses must be rigorously and openly researched and debated, as there are legitimate questions to be resolved. At a minimum, any person or organisation testifying or writing on risk assessment should be asked to declare potential conflicts of interest and sources of funding. Such a policy is now 
widely used by peer review journals and legitimate scientific conferences, and has most recently been recommended by another favourite tobacco industry target, the World Health Organization. ${ }^{30}$

It is time as well to put to rest any doubt that second hand smoke is an environmental hazard of substantial magnitude. Governments have a duty to protect their citizens from second hand smoke, treating this toxic cocktail as they would any other proven environmental hazard.

Support was provided to $\mathrm{NH}$ as consultant to the Tobacco Free Initiative of the World Health Organization; SAB was a WHO Global Health Fellow during the research.

1 Whelan E. Cigarettes: what the warning label doesn't tell you. Amherst, Massachusetts: Prometheus Books, 1997.

2 Hackshaw A, Law M, Wald N. The accumulated evidence on lung cancer and environmental tobacco smoke. $B M \mathcal{F}$ 1997;315:980-8.

3 Law M, Morris J, Wald N. Environmental tobacco smoke exposure and ischaemic heart disease: an evaluation of the evidence. BMF 1997;313:973-80.

4 Lash T, Aschengrau A. Active and passive cigarette smoking and the occurrence of breast cancer. Am F Epidemiol 1999; 149:5-12.

5 Bonita R, Duncan J, Truelsen T, et al. Passive smoking as well as active smoking increases the risk of acute stroke. Tobacco Control 1999;8:156-60.

6 US Department of Health and Human Services. Reducing tobacco use: a report of the Surgeon General. Atlanta, Georgia: tobacco use: a report of the Surgeon General. Atlanta, Georgia: US DHHS Centers for Disease Control and Prevention, National Center for Chronic Dis
Health Promotion, 2000, 195 pages.

7 US Environmental Protection Agency. Respiratory health effects of passive smoking: lung cancer and other disorders. US EPA, 1992. Publication No. EPA/600/6-90/006F. Washington, DC

8 US Department of Health and Human Services. The health consequences of involuntary smoking. A report of the Surgeon General, 1986. Rockville, Maryland: Public Health Service, Centers for Disease Control, 1986. (DHHS Publication No (CDC) 87-8398.

9 California Environmental Protection Agency. Health Effects of Exposure to Environmental Tobacco Smoke: The Report of the California Environmental Protection Agency. Bethesda, Maryland: NIH, 1999. (NIH Publication No. 99-4645).URL: www.oehha.org/air/environmental.tobacco

10 Boffetta P, Agudo A, Ahrens W, et al. Multicenter case-control study of exposure to environmental tobacco smoke and lung cancer in Europe. f Natl Cancer Inst 1998; 90:1440-50.

11 US Department of Health and Human Services. Ninth report on carcinogens. Research Triangle Park, North Carolina: USDHHS, Public Health Service, National Toxicology Program, 2000.

12 The Roper Organization Inc. A study of public attitudes toward cigarette smoking and the tobacco industry in 1978,Volume 1 Prepared for The Tobacco Institute. The Tobacco Institute. May, 1978. Accessed June 2001 Bates No.: TIMN 0064833/4885. Report URL: www.tobaccodocuments.org.

13 Pierce J, Gilpin E, Emery S, et al. Tobacco control in California: who's winning the war? An Evaluation of the Tobacco
Control Program. University of California, San Diego, 30 Control Progra 1998.

14 Glantz S. Changes in cigarette consumption, prices, and tobacco industry revenues associated with California's proposition 99. Tobacco Control 1993;2:311-14.

15 Glantz S. Back to basics: getting smoke free workplaces back on track. Tobacco Control 1997;6:164-6.

16 Manley M, Pierce J, Gilpin E, et al. Impact of the American Stop Smoking Intervention Study on cigarette consumption. Tobacco Control 1997;6(suppl):S12-16.

17 Anon. (Send to Ann. ETS World Conference). Philip Morris. 1994. Accessed March 2000 Bates No.: 2054893642/ 3656. Hand-written notes. URL: www.pmdocs.com

18 Anon. A Smokers' Alliance (Draft). Philip Morris. July 9 1993. Accessed June 2000 Bates No.: 2022839671/9727. Presentation. URL: www.pmdocs.com.

19 Hirayama T. Non-smoking wives of heavy smokers have higher risk of lung cancer: a study from Japan. BMF 1981; 282:183-5.

20 Trichopoulos D, Kalandidi A, Sparos L, et al. Lung cancer and passive smoking. Int $\mathcal{F}$ Cancer 1981;27:1-4.

21 Hirschhorn N. Shameful science: four decades of the German tobacco industry's hidden research on smoking and health. Tobacco Control 2000;9:242-7.

22 Anon. Philip Morris Incorporated, 1984 Corporate Affairs World Conference, Rye Brook, New York, 13 September 1984 Workshop: dealing with the issues indirectly: constituencies. Philip Morris. Accessed March 2000 Bates No.: 2025421934/2000. Transcripts. URL: www.pmdocs.com.

23 Ong E, Glantz S. Constructing "sound science": tobacco, lawyers, and public relations firms. Am J Public Health (in press).
24 Saloojee Y, Dagli E. Tobacco industry tactics for resisting public policy on health. Bull World Health Org 2000; 78:902-10.

25 Muggli M, Forster J, Hurt R, et al. The smoke you don't see: uncovering tobacco industry scientific strategies aimed against control of environmental tobacco smoke. Am $\mathcal{f}$ Public Health 2001:91:1419-23.

26 Drope J, Chapman S. Tobacco industry efforts at discrediting scientific knowledge of environmental tobacco smoke: a review of internal industry documents. F Epidemiol Community Health 2001;55:588-94.

27 Action on Smoking and Health UK. Tobacco explained: the truth about the tobacco industry ... in its own words. ASH-UK, 25 June 1998. London, 9 pages. URL: http://www.ash.org.uk/

28 Committee on Risk Assessment of Hazardous Air Pollutants-National Research Council. Science and judgment in risk assessment. Washington DC: National Academy Press; 1994. URL: http://www.nap.edu/catalog/2125.html

29 Anon. ETS World Conference Follow-up. Philip Morris. June, 1993. Accessed June 2000 Bates No.: 2028395330/ 5335. URL: www.pmdocs.com.

30 Committee of Experts on Tobacco Industry Documents. 2000. Tobacco Company Strategies to Undermine Tobacco Control Activities at the World Health Organization. WHO, July 2000. Geneva, 260 paages. URL: http://www.who.int/genevahearings/inquiry/html

31 Humber T. Memo to Ellen Merlo, cc Vic Han, Subject: ETS. Philip Morris. 1993. Accessed March 2000 Bates No.: 2024713141/3156. Memorandum. URL: www.pmdocs.com.

32 Anon. ETS Media Strategy. Philip Morris. February, 1993. Accessed March 2000 Bates No.: 2023920090/0101. URL: www.pmdocs.com.

33 Ong E, Glantz S. Tobacco industry efforts subverting International Agency for Research on Cancer's second-hand smoke study. Lancet 2000;355:1253-5.

34 Stauber J, Rampton S. Toxic sludge is good for you! Lies, damn lies and the public relations industry. Monroe, Maine: Common Courage Press, 1995

35 Colby F. Memorandum to Mr Max H Crohn, Jr. Re: Common interests of US industries, including the tobacco industry, on environmental health controversies. RJ Reynolds Tobacco Company. 20 May 1981, WinstonSalem, North Carolina. Accessed March 2000 Bates No.: 500927184. Memorandum. URL: http://docs.house.gov/ tobacco/docs $2 /$ rjisearch.htm.

36 Colby F. Memorandum to $\mathrm{Mr}$ Samuel B. Witt, III. Re: Common interests of US industries. RJ Reynolds Tobacco Company. 26 July 1982, Winston-Salem, North Carolina. Accessed March 2000 Bates No.: 505741610. Memorandum. URL: http://docs.house.gov/tobacco/docs2/ rirsearch.htm.

37 Anon. Second-hand smoke plan. RJ Reynolds. 6 April 1994. Accessed March 2000 Bates No.: 512046746/6749. URL: www.rirtdocs.com.

38 Winokur M. Memo to John Sorrells, cc to Deborah Becker, Marc Firestone, Vic Han. Subject: CRS plan - comments. Philip Morris. 7 March 1996. Accessed March 2000 Bates No.: 2048585226C/5227A. Memorandum (e-mail). URL: www.pmdocs.com.

39 Americans for Nonsmokers' Rights. The National Smokers Alliance: Exposed. A report on the activities of Philip, Morris' \#1 Front Group Americans for Nonsmokers' Rights. Accessed July 2001. URL: http://www.nosmoke.org/nsa.html

40 Agreement between Multinational Business Services, Inc. and Philip Morris Incorporated. Philip Morris. 1 January 1994. New York. Accessed February 2000 Bates No: 2029377064/7071. Agreement. URL: www.pmdocs.com.

41 Boland J, Borelli T. Memo to T Collamore Re: monthly budget supplement Re: ETS/OSHA Federal Activities. Philip Morris Management Corp. 17 February 1993, Washington, DC. Accessed April 2000 Bates No.: 2046597149/7150.

42 Fuller C. Letter to Mr Jim Tozzi, Chairman, Federal Focus Inc. Philip Morris Companies, Inc. July 13, 1993, New York, NY. Accessed March 2000 Bates No.: 2046597569. Letter. URL: www.pmdocs.com.

43 Kelly Jr W. Comments of proposed guidelines for carcinogen risk assessment. Federal Focus, Inc. 21 August 1996, Washington DC. Accessed March 2000 Bates No.: 2502256566/6577. URL: www.pmdocs.com.

44 Okoniewski A. Memo to "Distribution" Subject: risk assessment. Philip Morris International, Inc. 7 February 1992, Rye Brook, NY. Accessed June 2000 Bates No.: 2500016690. Inter-Office correspondence. URL: www.pmdocs.com.

45 The White House Office of the Press Secretary. For immediate release. The White House. 22 June 1992, Washington DC. Accessed September 2000 Bates No.: 2022852170. Press release. URL: www.pmdocs.com.

46 Anon. Update. Philip Morris.15 January 1994. Accessed September 2000 Bates No.: 2025482992/2997. Report. URL: www.pmdocs.com.

47 Auchter T. Statement of Thorne G. Auchter, Director, The Institute for Regulatory Policy At the Occupational Safety and Health Administration's Public Meeting on Standards Planning Process: The need for good epidemiological practices (GEPs) in studies used by regulatory agencies. practices (GEPs) in studies used by regulatory agencies. Whe Institute for Regulatory Policy. 21 November 1994, 2050240421/0431. URL: www.pmdocs.com. 
48 Auchter T. Memorandum to Mayada Logue. Subject: the proposal to classify exposure to secondary smoke as a disease. The Institute for Regulatory Policy. 17 January 1994 Washington, DC. Accessed June 2000 Bates No:

49 Auchter T. Memorandum to Mayada Logue. Subject: Follow-up memo to the inclusion of asbestos, latex, silicon, dioxin and PCBs into the ICD-9-CM. Multinational Business Service, Inc. 25 May 1994, Washington DC. Accessed June 2000 Bates No.: 2046073132/3133. Memo. URL: www.pmdocs.com.

50 Auchter T. Memorandum to Mayada Logue. Subject: the proposal to include secondary smoke as an external causative agent. Multinational Business Services, Inc. 8 March 1994, Washington, DC. Accessed June 2000 Bates No. 2025478338/8340. Memo. URL: www.pmdocs.com.

51 Renn C. Letter to the Coordination and Maintenance Committee, Department of Health and Human Services. Associated Industries of Florida Service Corporation. 22 Associated Industries of Florida Service Corporation. 22 February 1994, Tallahassee, Florida. Accessed June 2000 .com.

52 Tozzi J. Letter to the Coordination and Maintenance Committee, Department of Health and Human Services. Multinational Business Services, Inc. 2 February 1994, Washington DC. Accessed June 2000 Bates No.: 2025478346/ 8347. Letter. URL: www.pmdocs.com

53 ICD-9CM ICD9CM.chrisendres.com 23 July 2001. URL: http://icd $9 \mathrm{~cm}$. chrisendres.com/ icdcodecat.cgi?action=icdcodecat\&icdcodecat $=\mathrm{E} 869$

54 Tozzi J. Memorandum to Jim Boland, Tom Borelli, Ted Lattanzio. Multinational Business Services, Inc 29 December 1993, Washington DC. Accessed April 2000 Bates No. 2024207141/7142. Memorandum. URL: www.pmdocscom.

55 Seitz F. Global warming and ozone hole controversies: a challenge to scientific judgment. Washington DC: George C Marshall Institute, 1994. Accessed April 2000 Bates C Marshall Institute, 1994. Accessed April 2000 Bates
No.: 2501355990/6010. Book. URL; www.pmdocs.com.

56 Winokur M, Goodheart J. Memo to "Distribution" RE: Misuse of Science. Philip Morris Incorporated. March 9, 2501355988/5989. Inter-Office Correspondence. URL: 2501355988/5989.

57 Stokes C. RJR's support of biomedical research international advisory board. RJ Reynolds Tobacco. June 1979. Accessed March 2000 Bates No.: 504480506/0517 Speech. URL: http://www.rirtdocs.com.

58 Lyberpoulos H. Memo to various people Subject: Misuse of science: F Seitz' paper. Philip Morris Corporate Affairs Europe. 16 March 1994, Brussels. Accessed June 2000 Bates No.: 2501355987. Memorandum. URL: www.pmdocs.com.

59 Anon. (Welcome). Philip Morris. 1992. Accessed March 2000 Bates No.: 2024102283/2287. Speech/Presentation.

URL: www.pmdocs.com
60 International Agency for Research in Cancer. 1997. Polychlorinated dibenzo-para-dioxins. Lyon, France: IARC/ WHO, February. Monograph 69. URL: http

61 Tozzi J. Comments of Jim J. Tozzi on behalf of the Center for Regulatory Effectiveness concerning the NTP proposal to change the listing of TCDD ("dioxin") in the Ninth Report on Carcinogens to "known to be a human carcinogen". Multinational Business Services, Inc, Center for Regulatory Effectiveness. December 2, 1998, Washington DC. Accessed June 2000 Bates No.: 2502310465/0466. URL: www.pmdocs.com.

62 Anon. Legislation, regulations, and standards-White House. Philip Morris. March, 1997. Accessed June 2000 Bates No.: 2063589732/9734. Report. URL: www.pmdocs.com.

63 Center for Regulatory Effectiveness. Accessed June 2001. URL: http://www.thecre.com

64 Philip Morris Management Corporation. Comments concerning procedural issues in the development and use of NTP's ETS background document and the proposed listing of ETS as a known human carcinogen. Philip Morris Management Corp 1999, New York. Accessed March 2000 Bates No.: 2063778721/8740. URL: www.pmdocs.com.

65 Tozzi J. Memorandum to ETS working group. Multinational Business Services, Inc. 9 February 1999, Washington DC. Accessed March 2000 Bates No.: 2502139216. Memo. URL: www.pmdocs.com.

66 Valis W, Auchter T. Memorandum for CURE members. Subject: possible support for regulatory executive order. Coalition for Uniform Risk Evaluation. 24 September 1993, Washington DC. Accessed June 2000 Bates No.: 2024224722/4727. Memorandum. URL: www.pmdocs.com.

67 Coalition for Uniform Risk Assessment. Membership list. Coalition for Uniform Risk Assessment, Washington DC. Accessed June 2000 Bates No.: 2024211470. URL: www.pmdocs.com.

68 Lattanzio T. Note to Lattanzio, Ted Subject: 94 Proposals. Philip Morris. 11 October 1993. Accessed June 2000 Bates No.: 2045655962. Memo. URL: www.pmdocs.com.

69 Morgan D. Secret weapon of US corporations exposed. Leaked documents show how a think tank takes company Leakh and lobbies on behalf of big business. Washington DC: The Washington Post (reprinted in the Guardian Weekly), 2000:33.

70 Murphy T. Philip Morris smoking. Forbes.com 26 July 2001. URL: http://www.forbes.com/markets/2001/07/26/ 0726bigvalue.html

71 Rogers D. Survey - creative business: Tobacco Advertising FT.com Financial Times. 24 July 2001. URL: http:// globalarchive.ft.com/globalarchive/ articles.html?print $=$ true\&id $=010724001527 \#$ 